\author{
Rafał Solewski \\ (1) https://orcid.org/ 0000-0001-9631-9257 \\ Chair of Art Studies, Department of Humanities, Pedagogical University in Kraków \\ rafal.solewski@up.krakow.pl
}

\title{
ON SENSE AND ONESELF. TALE IN THE HERMENEUTIC INTERPRETATION OF THE ART OF JOSEPH BEUYS, ZBIGNIEW WARPECHOWSKI AND MIROSŁAW BAŁKA
}

\begin{abstract}
The article begins with the hermeneutical assumption that a response to the "call" of sense to discover it in the world and a statement finding the sense of personal identity in the "combination" of stability and changeability can meet in a work of art and its interpretation when the response and the statement are understood as a tale. Examples of such tales, the performative actions of Joseph Beuys who combined private dramatic experiences with recognizing himself as a shaman whose mission was to heal societies. Then, Zbigniew Warpechowski's mission and sacrifice are illustrated in the activities and consistent attitude within a performative and contemporary imitation of Christ and "avant-garde conservatism". Finally, the paper presents the reflective acceptance of one's own and universal heritage expressed in Mirosław Bałka's installations whose character, poetic and easy to interpret, has hidden meaning (sense). Owing to the art of the abovementioned artists, it is the interpretation of artistic activities understood as poetic tales that allows us to discover meaning at the metaphysical level where universal values are found.
\end{abstract}

Keywords: sense, identity, hermeneutics, tale, performance, installation, poetics

\section{Sense}

The belief that "the world is governed by a hidden sense that a human is tasked to discover" ${ }^{1}$ seems to be one of the fundamental assumptions of Władysław

1 W. Stróżewski, Logos i mythos, in: idem, Logos, wartość, mitość, Kraków 2013, p. 134. 
Stróżewski's philosophy. A response to this 'task', call or challenge gives birth to a myth, i.e. the manner of grasping the mystery of the sense (i.e. Logos - according to the philosopher, the term Logos, translated as Word, should also be translated as sense) by human cognitive powers.

The sense-revealing (Logos-revealing) response which gives birth to the myth is "translated" into a discourse or symbols. Therefore, the myth and its form are the product of translation.

Learning the myth of a religious nature allows us to directly participate in the "arche" and thus to have a direct experience of the Logos, i.e. sense. Apart from this myth, various mythoi or different ways of understanding "the hidden sense" ${ }^{2}$ emerge. Stróżewski separately discusses the mythoi of philosophy, science and poetry.

\section{The mythos of art}

Although the philosopher does not talk about it directly, perhaps it is also worth reflecting on the mythos of art or visual arts, i.e. viewing art as "a manner of understanding the hidden sense" or discovering the sense which governs the world.

As for the mythos of art, it seems that a response to the call for discovering the sense would be translated into artworks, most often images. Yet, the contemporary understanding of art indicates that its mythos today comprises intermedial works and performative actions understood as art, designed for polysensory reception.

It seems that such artworks, i.e. responses to the call for discovering the sense 'translated' into the modern language of the mythos of art, should be a testament to the Logos, i.e. the Word, according to Stróżewski. That would justify treating them as tales.

\section{Hermeneutics}

The presence of the word first occurs through the fact that an artwork, if considered an intentional creation, exists due to our consciousness and thought which makes use of the word ${ }^{3}$. However, the tale appears to be the most visible in a hermeneutic interpretation explaining the artwork which responds to the call of the sense. The understanding of an artwork and its interpretation as

\footnotetext{
Ibidem, p. 136.

See W. Stróżewski, Dialektyka twórczości, PWM, Kraków, 1983, pp. 76-78 and idem, Wartości estetyczne i nadestetyczne [in:] idem, Wokót piękna. Szkice z estetyki, Universitas, Kraków 2002, pp. 198-202.
} 
a tale may point to the characteristics of a statement present in visual and performative works, and their reception.

\section{A tale of oneself as of another ...}

Paul Ricoeur's hermeneutic reflection indicates that a statement implies questions: who makes the statement, who they address, as well as who or what they talk about, which is particularly important for the philosopher. This is because he proposes to 'hybridise reflectivity and an identifying reference' 4 which are present in answers to these questions in relation to an individual's identity. 'Hybridisation' combines the sense of corporeally restricted subjective immediacy at a moment in time with localising and identifying naming that is often 'institutionalised' by our giving permanent names and surnames. The role of the word is not only to name,but also to be a point of reference. This is because the relationship between an objective individual and a subject engaged in reflection also includes the dialectics of idem identity, i.e. being the same a permanent genetic structure, but also a substance that changes its properties under the influence of time, as well as of ipse identity, i.e. being the one who is oneself, the one who endeavours to be faithful to the word given. ${ }^{5}$ According to Ricoeur, 'selfhood' is a process that is intuitively undertaken by a human, ethically characterised and self-interpreting. It comprises turning towards oneself in a narration which allows one to combine the constancy and permanency of 'I' that is loyal to oneself and one's own word with the diversity, changeability and inconsistency of oneself that constantly becomes another. Narrative identity becomes an intermediary in the dialectics of 'being oneself and being the same'.

Therefore, the narration on one's permanent self simultaneously understood as another, susceptible to changes, lets one discover one's own identity, or even the sense of one's own identity, if it is not an exaggeration. For Ricoeur, keeping the word is of fundamental significance to one's identity. It is precisely in the word, understood as the source - Logos that Stróżewski would find the sense. ${ }^{6}$

Therefore, the described narration, as well as the statements-works embodying the mythos of art let us respond to the call of sense that wants to be discovered. Two responses to the call of sense may meet within an artwork - ones that reveal it through a work-statement and identity-related narration.

4 P. Ricoeur, $O$ sobie samym jako innym, translated by Bogdan Chałstowski, PWN, Warszawa 2005 , pp. 90.

5 Cf. ibidem, p. 33-34, 190-191, 233n.

6 Notably, also Ricoeur uses the notion of mythos in Aristotelian meaning, cf. ibidem, p. 238. 


\section{... and its 'replenishment' through the reception of an artwork}

A meeting of responses to the call of sense to discover it in an artwork, interpreted as a statement with internal narration that lets us discover the sense of one's own identity, may result in an artwork or an artistic action, when an artist conducting internal narration transposes it onto a universal level. According to another hermeneut, Hans-Georg Gadamer, it is this transposition that transforms one's own experience into an artwork, which is experienced in its reception. Writing about 'complement' and 'fulfilment' in relation to an artwork, the philosopher emphasised the ultimate role of 'replenishment' - Auffülen. On this level, one transcends beyond the work and egoistic individuality: 'any opposition between thought and being, artist and recipient disappears', and what results from self-examination and self-exploitation 'becomes transformed from privacy, autobiography into what is universal', which constitutes the underlying reason why artworks allow everyone who enters their orbit to encounter their true selves. ${ }^{7}$

According to this thought, reaching the universal sense-revealing level thanks to an artwork allows one not only to add to and complement one's personal narration, but ultimately replenish it with the discovered universal sense which, returning to Stróżewski's thought, is identical with the Logos.

The 'replenishment' described by Gadamer occurs in hermeneutic interpretation. Therefore, what seems to be the artistic imperative is not only the need to reach the universal level, but also to make it available through artworks as the sense that they reveal. Gadamer writes about all 'those' who encounter themselves by entering the 'orbit of an artwork', so perhaps, presumably, there should be many recipients of a work of art. The internal narration about oneself as another, discovering not only its own, but also the universal sense by becoming the matter of an artwork should, therefore, build a relationship with another, not only the one who meant myself.

Therefore, adding to the narration, i.e. filling it with the Logos, is open towards another. This is achieved thanks to hermeneutic interpretation which explains why and how the mythos of art meets the narration about oneself as another.

The selected artistic examples may indicate instances of a directly expressed need to transfer one's own experience, which constitutes the object and tool of narration, to the universal level, simultaneously made available to another, through the mythos of art. Making it available in this way may be accompanied

7 Cf. H.-G. Gadamer, Koniec sztuki? Od heglowskiej nauki o przesztościowym charakterze sztuki do dzisiejszej antysztuki [in:] idem, Dziedzictwo Europy, translated by Andrzej Przyłębski, Spacja, Warszawa 1992, p. 53. 
by a reflection on how difficult it is nowadays to transfer the call of sense to another and reveal it to them.

\section{Joseph Beuys}

For Joseph Beuys, the starting point was his experience of being brought up in a religious family and surviving a plane crash after being shot down during the war. He enriched the experience with his imagination and developed it into reflections on universal truths and values independent of borders, albeit adjusting their expression to the changeability of place and time. His religious and poetic sensitivity accompanied by sculptural skills that were originally transformed into social art resulted in artistic activities which were directly called tales or it was indicated how they made use of the tale.

In a performance piece entitled How to Explain Pictures to a Dead Hare (1965), the artist walked along art gallery walls with his head 'anointed' with honey, touching pictures with the paw of a dead hare he held in his arms. $\mathrm{He}$ would later sit down and explain the pictures to the animal. Relating directly to the hare as a symbol of reincarnation and rebirth, and to honey as a naturally produced and revitalising substance which acts like human thoughts, the artist combined symbols with speech, since growth stemming from the creative force may be spiritually grasped in the uttered word. ${ }^{8}$ Simultaneously, the tale about art did not reach the spectators remaining outside the room where the performance was taking place, which is sometimes also interpreted as a symbolic indication of a society's indifference, its lack of sensitivity and the resulting need to heal and be reborn. The role of art is to be a remedy for the lack of sensitivity and to become, just like religion, space for understanding the sense of existentially inevitable suffering and death that we all need to face, pushed out from thought by modern societies. ${ }^{9}$

The remedy is to be the work of a shaman who draws wisdom from tales and spins tales himself. Partaking in the metaphysical source of wisdom, he teaches and possesses the power of healing that Beuys had wanted to have in his childhood days. The coyote, which appears in tales and who the shaman may identify with, transcends the borders between nature and the human. Already as the shaman, he guides the human in the afterlife when he or she, awakened to feel, experiences inevitable suffering and death. ${ }^{10}$ 'Awakened', but as the coyote

8 Cf. How to Explain Pictures to a Dead Hare, https://en.wikipedia.org/wiki/How_to_Explain_Pictures_to_a_Dead_Hare (08.05.2020).

9 Cf. Donald Kuspit, A Critical History of 20th-century Art, http://www.artnet.com/magazineus/features/kuspit/kuspit8-9-06.asp (08. 06. 2020).

10 David Levi-Strauss, American Beuys: "I Like America \& America Likes Me", https://nbrokaw. files.wordpress.com/2010/12/american-beuys.pdf (08.05.2020). 
again, he teaches the hare, which symbolises reincarnation and rebirth, how to survive and adapt. The coyote, who had once crossed the border between Asia and America, and adapted, is part of Beuys' tale of himself as a shaman and himself as the survivor of a catastrophe, when he was saved by nomadic Tartars (probably only imagined in the role of 'rescuers') who cultivated shamanism and also did not recognise the border between Europe and Asia. Beuys locked himself in a room with a real animal as part of the performance I Like America \& America Likes Me (1974), to make shamanic unification possible in his art, so that he could use it to heal the wounded and indifferent society. The artist found it to be the matter of sculpture, technique and domain from which he embarked on his artistic activity. ${ }^{11}$ The tale of the shaman as a healer of society thus became part of social art. One of its representative actions consisted in planting seven thousand oak trees during the Documenta 7 exhibition in 1982. During the event, the artist creatively became part of nature, participating in the development of its creative force, symbolically building a community and providing a template for a participative action transcending the borders between nature and culture, shaping an organism composed of many parts. It was an important template: according to the idea of 'social sculpture', anyone who consciously uses freedom (e.g. through direct choices) becomes an artist, creating the social organism as a total work of art. ${ }^{12}$ The symbolism was extended by the creator's spiritual sensitivity. The saplings were fragile and weak, in contrast to hard and solid pieces of rock placed next to them (one by each small tree). With time, however, the trees will be growing, climbing up, becoming stronger, boldly existing within the landscape to last for long. Meanwhile, the stones will grow weather-beaten and they will ultimately fall apart. Beuys stated directly that when the wind moves the treetops, they are permeated with the same substance that is brought to the earth by suffering people and that there is a Sacrament in the treetops, and this is why trees must be protected, ${ }^{13}$ as if he was invoking Christ's words: 'The wind blows wherever it pleases' (J 3,8). ${ }^{14}$

The tale, Eurasian or transcontinental at the same time, of himself as a survivor participating in shamanic rituals was added to by the installation Lightning with Stag in Its Glare (processually created until the artist's demise in 1985). It combined elements left of a crashed plane with materials used to save

11 Caroline Tisdall, Art into Society, Society into Art, ICA, London, 1974, p. 48.

12 J. Beuys, Każdy artysta, translated by Krystyna Krzemień [in:] Wspótczesna myśl estetyczna. Wybór tekstów, Ryszard Różanowski (ed.), Wydawnictwo Uniwersytetu Wrocławskiego: Wrocław 1993, p. 29.

13 Cf. artist's statements [in:] Friedhelm Mennekes, Beuys zu Christus. Eine Position im Gespräch, Katholisches Bibelwerk, Stuttgart 1989, pp. 47-49.

14 The Gospel of John, https://biblehub.com/niv/john/3.htm (11.06.2020). 
Beuys' life: deerskin suspended like a protective tepee, as well as felt and fat that were also displayed in his other installations together with wax, as substances that accumulate natural energy needed for transformation and rebirth. The lightning in the title may suggest the source of the energy. It took the form of a crooked stick in the work and was also interpreted as 'Beuys' Eurasian staff' or the shamanic staff of a messenger and mediator ${ }^{15}$.

The reflective tale about oneself, taking advantage of its own experiences and artistic skills was, thanks to these skills, transformed into an artistic tale that was metaphorically called a myth, but rather made use of myths and became part of the mythos of art, artistically revealing the sense in the shaman's (social healer's) mission. The therapeutic action, along with the 'preaching' of science used by the shaman towards himself and the society, encompassed both the experienced suffering and the facing of death. This made one more sensitive to them, but also allowed for rebirth, transformation, protection, transcendence and connection. In a way characteristic of the shaman, the tale revealing the beginning and explaining the sense of life was connected with treatment. As it seems, the sense was then indicated by implementing the values of the truth (truth taught in the tale and included in the symbols) that belonged to it and were metaphysically attached. On the one hand, art that was perceived with difficulty could remind us that the truth about suffering is also difficult to accept. Meanwhile, it makes sense just like death does and thus the two should always constitute points of reference for one's personal identity. Death and suffering both belong to the idea of humanity and are part of living in this world. However, the society forgets about this truth and thus becomes mutilated. On the other hand, the truth that was being taught was embodied in action and in an attitude that was faithful to an idea. This is because the activity of the artist-shaman-healer seemed to stem from the desire to do good to another, to experience the healing and be creative together, and from love capable of sacrifice to oppose death by reincarnation, transformation and rebirth. In his creative life, Beuys was faithful to these values. His attitude stemmed from values unchangeable for the 'self' engaged in personal narration, the 'self' that maintained these values when faced with the changing world and time in which he was observing and turning himself into an object of a statement as yet another 'another'. At the same time, these statements, i.e. artistic works and actions arising from the various changing situations would return to the level of sense and idea on their own, due to belonging to the mythos of art and being endowed with a poetic quality (usually symbolic for Beuys), thanks to the value of the poetic beauty.

15 Cf. D. Levi-Strauss, op. cit. 
A reference to the situation of a shaman in contemporary society was made by Jeff Wall in the work created a year after Beuys' death. Although it does not directly refer to the activity of the German sculptor and performer, and was made using a different technique, one cannot help feeling that 'zeitgeist' had some influence on it, inspiring the artist to write a visual post scriptum for the earlier invocation of the shaman in contemporary art. The impression is even stronger due to the fact that Beuys's and Wall's artworks are sometimes juxtaposed in the context of both socially and spiritually sensitive art. ${ }^{16}$ In a photograph displayed, typically for Wall, as a large lightbox, ${ }^{17}$ The Storyteller mentioned in the title is one of the five depicted individuals clad in contemporary jeans-and-flannel clothes with various patterns that do not let us distinguish their gender. Associations with a picnic or fete galante, i.e. impressionist 'breakfast', but from the end of the $20^{\text {th }}$ century, are suppressed by the initial impression of the overwhelming concrete highway overpass occupying almost one-third of the picture. It is underneath this overpass that the meeting is taking place. A closer look at the figures reveals their long black hair indicative of their Indian roots or, as suggested by the descriptions, belonging to 'Native Americans'.

The 'storyteller' is the one 'chosen' not only by the community, one who sees and knows the truth hidden in tales, and one who tells them, as well as the shaman ${ }^{18}$ who heals through them. He uses a fire to perform a ritual - a fire that is flimsy, just like the culture which used to have its own way of becoming open towards metaphysical truth. The symbolic fire is replaced with the light of the lightbox: strong, modern in terms of 'illumination', since cleverly installed, yet artificial. Under the busy highway teeming with heavy traffic, the tale is likely to be barely heard and the rationally 'domesticated' community that has been colonised, dominated and pushed into the peripheries is probably finding it difficult to sensibly participate in it. There is almost no one to listen to the shaman, so perhaps it would be better for him to be talking to the dead hare that embodies the hope for rebirth. The poetic symbolism of fire and

16 Jan Koenot, When the Body Speaks Louder than Words. The Image of the Body as a Figure of the Unknown [in:] Fluid Flesh: The Body, Religion and the Visual Arts, Barbara Baert (ed.), Leuven University Press, Leuven 2009, p. 18.

17 It is a cuboid showcase with a light source inside, suspended on a wall. Its whole largest external surface $(2,290 \times 4,370 \mathrm{~mm}$ in this case $)$ is a slide. Cf. The Storyteller 1986, Tate, http://www.tate.org.uk/whats-on/tate-modern/exhibition/jeff-wall/room-guide/jeff-wallroom-4 (02. 07. 2013).

18 'A shaman is a permanent element of social life, his institution is indispensable for his community. Thanks to initiation, the shaman has the relevant knowledge needed in difficult situations, when he has to go to the otherworld to help individuals or the entire community' Cf. Szaman, http://pl.wikipedia.org/wiki/Szaman (01.03. 2013). 
the 'storyteller' which allows the artist to maintain an association with Beuys, complemented by the motif of the highway overpass that is metonymically adjacent to the total modernity and builds a new context for the shamanic ritual, is transformed into subversion. Wall's potential 'post scriptum' is more critical than Beuys's social mission. ${ }^{19}$ Not so much does the tale reveal the sense and announce its call, as it criticises the loss of the metaphysical tale which used to allow one to find the sense.

Mission expressed through action, statement and attitude is important for Zbigniew Warpechowski. It stems from his own experience, but helps one respond to the call of sense in art, in order to find it on the metaphysical level. Similarly as in Beuys's art, the tools of response combine sculptural and performative actions making use of the body and its sensitivity, along with poetic thinking and the preached word that the Polish artist published in books. This is because the texts included in them demonstrate how much the word of interpretation belongs to the work understood as a response to the call of sense. The very titles of the collections are meaningful: Podręcznik [Manual], Zasobnik [Container], Podnośnik [Jack], Statecznik [Stabiliser], Podręcznik bis [Manual Encore], Wolność [Freedom] and Konserwatyzm awangardowy [Avant-Garde Conservatism]. The books provide 'a record of discovering, building and cultivating a conscious intellectual reflection that is yet also homogeneous with the artistic practice' and simultaneously constitute a testament to the 'sensitivity to the matter of the word', as well as adopt it as a tool of one's art. ${ }^{20}$ It is as important as performance - the domain which the creator is mostly identified with as a neo-avant-garde artist. Yet, the poetic quality of such activities has also always been emphasized. It is most clearly visible in an interpretation that makes use of the word.

Perhaps the first Polish examples of performance art, Improwizacje [Improvisations] and Kwadrans poetycki z towarzyszeniem adapteru i fortepianu [Poetic Quarter with Record Player and Piano Accompaniment] from 1967, resulted from inspiration gained by Warpechowski during improvised poetry sessions held by Promieniści [the Radiant Association] from Vilnius. This already pointed to his being rooted in the Polish heritage and tradition of Romanticism, co-created by the search for ways of opening the space of metaphysics and discovering the sense governing the world there. At the same time, the artist explored the

19 On the difference between critical art that ironically takes advantage of utilized mass messages and social art that implies the co-formation of a community cf. Grzegorz Dziamski, Sztuka u progu XXI wieku, Fundacja Humaniora, Poznań 2002, pp. 70-72.

20 Sebastian Stankiewicz, Konserwatyzm awangardowy Zbigniewa Warpechowskiego i zasada odtwarzania dziedzictwa [in:] Dziedzictwo i odpowiedź w sztuce wspótczesnej/Heritage and response in contemporary art, Łukasz Murzyn, Rafał Solewski, Sebastian Stankiewicz, Bernadeta Stano (eds.), Wydawnictwo Naukowe UP, Kraków 2018, p. 238. 
ultimate boundaries of experience provided by the medium of his own body, in a manner characteristic of the neo-avant-garde. In 1978, the artist's bodily experience becomes the suffering of the crucified Christ in the performance Champion of Golgotha. In a manner characteristic of him, the artist will add to the performance (repeated and developed until the 1990s) in a later publication, indicating that action embedded in religion became the criticism of thoughtless idolatry created by 'managers'. As part of it, the bitter taste of vinegar offered to the Crucified, when 'the most important and most momentous drama of the human in an extraordinary condensation' 21 transpires, is replaced with the sweet and pleasant taste of Coca-Cola which results in the popularity of the product and is conducive to generating profit from its sales. The subversive transposition of Christ's suffering into the context of popular culture poetically criticised its superficial indifference towards pain and suffering whose sense is discovered by understanding them as a sacrifice borne out of love for the human, for the human's salvation.

In the critical performance Obywatelstwo dla czystego odczucia Kazimierza Malewicza [Citizenship for a Pure Sensation of Kazimir Malevich] (1985), the artist lay under a reproduced Black Square, the fundamental work of the Avant-Garde, covered with a duvet with a square opening and subjected himself to whipping (by another artist, Natalia LL) which left a 'whipped' square shape on his back. ${ }^{22}$ The physical suffering which condensed the 'pure sensation' propagated by Malevich was offered to him as redress for the 'Polish stupidity, opportunism, and cowardice' ${ }^{23}$ of the authorities of the Second Polish Republic which refused to grant Malevich Polish citizenship. The physical experience constituted a continuation of the pattern of action set out by Christ, who had also been whipped, and homage paid to the Avant-Garde. The artist responded to its heritage, but also expressed his concern for Poland whose rulers should learn how to perceive contemporary art, so that it could become Polish heritage. This is the reason why it is worth making a sacrifice. The avant-garde performance assumes the characteristics of the contemporary allegory of a romantic artist who bears a sacrifice for the nation in a manner suggested by his religion. Lastly, in his own statements, the artist directly emphasises his simultaneous relationship with the Avant-Garde and attachment to religion and heritage (national as well): 'In spite of everyone, I admit belonging to the Avant-Garde, similarly as I do not hide my attachment to the faith in God and the Church

21 Z. Warpechowski, Zasobnik. Autorski opis trzydziestu lat drogi życia poprzez sztukę performance, stowo/obraz terytoria, Gdańsk 1998, p.

22 Cf. Zbigniew Warpechowski, Obywatelstwo dla czystego odczucia Kazimierza Malewicza https://artmuseum.pl/pl/filmoteka/praca/warpechowski-zbigniew-obywatelstwo-dla-czystego-odczucia (20.05.2020).

Ibidem. 
of my ancestors. And I see no contradiction in that; to the contrary, the spiritual bond with the supreme good and Wisdom give me a sense of power and freedom, as well as energy and space for artistic raptures not restricted by any ideologies. ${ }^{24}$

'Avant-Garde Conservatism' and 'permanent renewal of heritage' are the guiding principles of Zbigniew Warpechowski's art - the principles which, although named in time, seem to have been faithfully adhered to throughout his entire creative life. ${ }^{25}$ They combine the vision of theurgy, i.e. "the cooperation of God and free man in a creative act" and understanding of re-creativity as 'following the supernatural model' characteristic of conservatism, with 'the idea of free creation of reality, as propounded by the avant-garde. ${ }^{26}$

Warpechowski's art can be connected with contemporary Romantic messianism where Poland, drawing upon the heritage of both John Paul II and Witold Gombrowicz, constitutes the beginning of a total communal artwork capable of transforming the world. ${ }^{27}$ It is due to the fact that it investigates an experience that is simultaneously sensory and spiritual; has a poetic quality whose sources, according to many, are metaphysical - like those of religion ${ }^{28}$, exploits one's own heritage, i.e. what 'has been given' to the artist and, lastly, presents a credible and consistent ethical attitude, i.e. 'keeping the word' directly present in book statements. The aforementioned total work of art can be understood as an attempt to seize the entire mythos of art in order to perfectly achieve its goal, i.e. to respond to the call of the sense governing the world. Such a response allows us to learn that sense, i.e. to discover that, in the world, the sense originates from the metaphysical. Zbigniew Warpechowski's whole artistic life, understood as avant-garde conservativist's intermedial narration 'permanently renewing the heritage', falls within this response. Through its time-transcending durability, the heritage indicates its metaphysical character and thus serves the purpose of discovering the sense.

A tale based on heritage, one that expands inspiration into a universal reflection using points of reference that are important for it, seems to be spinning in the creative work of Mirosław Bałka. Although he is a sculptor and installation-maker who chooses performative and verbal expression less often than

24 Z. Warpechowski, Statecznik, BWA, Lublin 2004, p. 322.

25 Cf. Z. Warpechowski, Konserwatyzm awangardowy, Otwarta Pracownia, Kraków 2014; idem, Konserwatyzm awangardowy 2, "Pressje", 2015, no. 43, p. 210-213 and S. Stankiewicz, op. cit., pp. 239-242.

26 Łukasz Murzyn, Terytorium refleksji. Dziedzictwo i sztuka nieco inaczej [in:] Dziedzictwo $i$ odpowiedź..., p. 225. Cf. Paweł Rojek, Awangardowy konserwatyzm. Idea polska w późnej nowoczesności, Ośrodek Myśli Politycznej, Kraków 2016.

27 Cf. Ł. Murzyn, op. cit., p. 227.

28 Cf. Czesław Miłosz, Zniewolony umyst, Krajowa Agencja Wydawnicza, Kraków 1989, p. 87. 
Beuys or Warpechowski, he does so in a meaningful manner. He also directly emphasises that he "writes poetry'29 in his works. A poetic tale of himself, yet within the sphere of the mythos of art, commences with Pamiatka Pierwszej Komunii [First Communion Souvenir] (1985) - a figure of a boy in a first communion suit, leaning against a small table with an embedded photograph of a child. During dissertation defence held in an abandoned, hard to reach, provincial house, professors drove needles into the red cushion in the place of the figure's heart.

The allegorical suggestion of the rite of passage into maturity expanded into metaphorical juxtapositions of bearing humiliating pain and staying 'tough' in spite of it. It was demanding, yet taken over from one's parents and teachers, but, first and foremost, anchored in the metaphysical sense of an initiatory ceremony opening one to the dimension of the sacrum.

The connection of art with this dimension was sustained by implementing the subject of sacredness in an installation entitled Święty Wojciech [Saint Adalbert $]$ of 1987. Artificial and modern materials used to produce the hanging elements: the mutilated body of the martyr, a neon-illuminated red axe and green drops dripping off the body were placed in a juxtaposition with a transformer, the dry soil of the base and a wooden chest with sprouting and nurtured oats. The intense energy of the world seemed to suppress and overwhelm nature by it effective action. Yet, the latter, when taken good care of, was to yield abundant harvest from the seed sown, similarly as St. Adalbert's martyrdom yielded spiritual fruit. The poetic parallel provided the basis for the 'harvest of martyrdom' metaphor, thanks to the sacrifice revealing the sense concealed in nature, despite one's apparent submission to the world. The sense is discovered through the heritage acquired at home (the artist directly recalled 'that in his family home green oat sprouts appeared in the Easter basket') and the inscription of his own predicted (artistic) fate within a universal metaphor, since the creator also claimed: 'in choosing protagonists, I always used some sort of camouflage but, in truth, I was interested in the figures of martyrs that expressed my own fears. ${ }^{30}$ Visually and poetically 'writing' about another, the artist spoke about himself.

The artist implemented symbolic meanings transferred into a universal dimension in his later realisations: Around $21^{\circ} 15^{\prime} 00^{\prime \prime} E 52^{\circ} 06^{\prime} 17^{\prime \prime} \mathrm{N}+$ GO-GO (1985-2001), Ruhe (2002) or Lebensraum (2003), in spaces close to environ-

29 Cf. Piszę poezje, ale używając formy, Rafał Jakubowicz interviews Mirosław Bałka, "Czas Kultury”, 1998, 6, pp. 94-99.

30 Cf. Korespondencje. Sztuka nowoczesna i uniwersalizm, ed. Jarosław Lubiak, Małgorzata Ludwisiak, Muzeum Sztuki in Lodz, Łódź 2012, p. 482. Also Każdy chłopiec boi się inaczej, Bożena Czubak interviews Mirosław Bałka, "Magazyn Sztuki”, 1998, no. 3 (19), pp. 16-31. 
mental art. These included the coordinates and a small-scale model of his family house in Otwock, tombstones with the titles of exhibitions etched in terrazzo by the artist's father, childhood memories triggered by an ashtray in the form of a Negro boy, as well as an illuminated acrylic glass tomb with a little plastic frog on top, accompanied by a trampoline leading outside and an illuminated reversed cross which matched the view from another window. Transforming artificial acrylic glass or scorned terrazzo through the symbolism of light, the cross and of reaching beyond limited space transferred the artist's own memory onto the level of metaphysics thanks to the poetic character of the visual story that turned it into an element of the mythos of art.

Mirosław Bałka made his definitive entry onto the universal level through a huge steel container: $13 \mathrm{~m}$ tall, $10 \mathrm{~m}$ wide and $30 \mathrm{~m}$ long, exhibited in Tate Gallery in London, within the space of the former Turbine Hall. ${ }^{31}$ Visitors would enter its completely dark and soundproof interior. The monumental 'box' of 2009 evoked possible associations with the 'existential void' already seen in Bałka's earlier actions, ${ }^{32}$ but also with the experience of imprisonment, alienation and death characteristic of victims of the Holocaust which destroyed the nation that co-created the heritage of the culture which provided a point of reference for the artist. This was where the earlier installation Winterreise (2003) was pointing to - roe deer filmed while grazing indifferently among the ruins of Auschwitz to the accompaniment of Franz Schubert's songs on loneliness. At the same time, the title How it is was a reference to Samuel Beckett's work on the recapitulation of life performed by a 'barely panting' narrator swimming through endless mud and only from time to time encountering a companion. ${ }^{33}$ Although it is a hopeless situation for Beckett, the mute and dark depth is sometimes interpreted in the context of purgatory, paradoxically reminding us of the desire for purification. Although the frightening emptiness and helplessness of the senses in Bałka's work also brought to mind the metaphysics of evil, visitors always had the soothing knowledge that there was a way out. Inside, one could also meet another - a Beckettian companion, a Holocaust survivor or anybody one could have a relationship with - a person one needed to discover the sense in the encounter, possible dialogue and community, and to be an indispensable part of the tale. It is because the one who spins the tale, even if they speak of themselves as of another, wants to speak not only to themselves, but also to another who is listening. The need to tell someone a tale in order to experience

31 Cf. Karolina Majewska, Skala. Mirostaw Batka w Tate Modern, “Arteon”, 2009, no. 11 (115), p. 6-9.

32 Cf. Rafał Jakubowicz, Obecność, pustka i brak, “Format”, 1999, no. 2-3 (31-32), p. 23.

33 Cf. How It Is, http://en.wikipedia.org/wiki/How_It_Is (16. 03. 2012). 
the call of the sense for its discovery together arises because the call of the sense is addressed to everyone and the sense is revealed in the relationship.

A hermeneutic interpretation of multiple meanings of the symbolic container added the thought on purification from evil in a relationship with another to the first associations - a relationship that allows one to discover the sense, i.e. to stand in metaphysical light. The metaphysical experience was also possible thanks to art, ultimately 'replenishing' Bałka's work in a hermeneutic interpretation. The actions of adding to it and 'replenishing' it through verbal reflection seem to maintain the possibility of approaching Bałka's whole creative output as a tale based on the encounter of unchanging poetic and spiritual sensitivity that is open to the sacrum, in one's own developing and changing experience of accepting the heritage.

\section{Tale as a reference to the level of metaphysics}

The presented hermeneutic interpretations complemented the described artistic activities derived from one's own experience and heritage: the narration about oneself as a shaman, styled as a myth and presented in a performative manner; the process of becoming one who makes a sacrifice of oneself in performative actions, published statements and one's own attitude; symbolic labelling condensing the entire creative work into a poet's tale 'written' with works on the borderline between environment and installation. The narration-tale of oneself as the same, experiencing what is one's own in one's body and memory, and the tale of oneself as another - the shaman, victim or poet, placed within artistic frames thanks to the figure of another, was becoming part of the mythos of art. The way it was happening, as well as the goal of the process were indicated in a hermeneutic interpretation explaining the mythos of art and its correspondence with the mythos of poetry. The interpretation made it clear how, by transferring "himself" or his "selfhood" onto a universal level, achieved when one's own story becomes poeticising art, an artist best responds to the call of the sense that is addressed to all. Thanks to art, one's own tale fulfilled its task of responding to the call of the sense and revealing it, as it referred seeing oneself as another, as well as every other person entering into a relationship with the artist and becoming the one who listens to the story, to the level of metaphysics - a place of unchanging values determining the sense. 


\section{BIBLIOGRAPHY:}

Beuys Joseph, Każdy artysta, translated by Krystyna Krzemień [in:] Wspótczesna myśl estetyczna. Wybór tekstów, Ryszard Różanowski (ed.), Wydawnictwo Uniwersytetu Wrocławskiego: Wrocław 1993, pp. 27-31.

Dziamski Grzegorz, Sztuka u progu XXI wieku, Fundacja Humaniora, Poznań 2002.

Gadamer Hans-Georg, Koniec sztuki? Od heglowskiej nauki o przeszłościowym charakterze sztuki do dzisiejszej antysztuki [in:] idem, Dziedzictwo Europy, translated by Andrzej Przyłębski, Spacja, Warszawa 1992, pp. 41-53.

The Gospel of John, https://biblehub.com/niv/john/3.htm (11.06.2020).

How It Is, http://en.wikipedia.org/wiki/How_It_Is (16.03.2012).

How to Explain Pictures to a Dead Hare, https://en.wikipedia.org/wiki/How_to_Explain_Pictures_to_a_Dead_Hare (08.05.2020).

Każdy chłopiec boi się inaczej, Bożena Czubak interviews Mirosław Bałka, "Magazyn Sztuki”, 1998, no. 3 (19), pp. 16-31.

Jakubowicz Rafał, Obecność, pustka i brak, "Format”, 1999, no. 2-3 (31-32), pp. 21-23.

Koenot Jan, When the Body Speaks Louder than Words. The Image of the Body as a Figure of the Unknown [in:] Fluid Flesh: The Body, Religion and the Visual Arts, Barbara Baert (ed.), Leuven University Press, Leuven 2009, pp. 3-24.

Korespondencje. Sztuka nowoczesna i uniwersalizm, Jarosław Lubiak, Małgorzata Ludwisiak (eds.), Muzeum Sztuki in Lodz, Łódź 2012.

Kuspit Donald, A Critical History of 20th-century Art, http://www.artnet.com/magazineus/features/kuspit/kuspit8-9-06.asp (08. 06. 2020).

Levi-Strauss David, American Beuys: "I Like America \& America Likes Me", https://nbrokaw.files. wordpress.com/2010/12/american-beuys.pdf (08.05.2020).

Majewska Karolina, Skala. Mirostaw Batka w Tate Modern, “Arteon”, 2009, no. 11 (115), pp. 6-9.

Mennekes, Friedhelm Beuys zu Christus. Eine Position im Gespräch, Katholisches Bibelwerk, Stuttgart 1989.

Miłosz Czesław, Zniewolony umyst, Krajowa Agencja Wydawnicza, Kraków 1989.

Murzyn Łukasz, Terytorium refleksji. Dziedzictwo i sztuka nieco inaczej [in:] Dziedzictwo i odpowiedź w sztuce wspótczesnej/Heritage and response in contemporary art, Łukasz Murzyn, Rafał Solewski, Sebastian Stankiewicz, Bernadeta Stano (eds.), Wydawnictwo Naukowe UP, Kraków 2018, pp. 213-232. 
Pisze poezje, ale używajac formy, Rafał Jakubowicz interviews Mirosław Bałka, "Czas Kultury”, 1998, 6, pp. 94-99.

Ricoeur Paul, O sobie samym jako innym, translated by Bogdan Chałstowski, PWN, Warszawa 2005.

Rojek Paweł, Awangardowy konserwatyzm. Idea polska w późnej nowoczesności, Ośrodek Myśli Politycznej, Kraków 2016.

Stankiewicz Sebastian, Konserwatyzm awangardowy Zbigniewa Warpechowskiego i zasada odtwarzania dziedzictwa [in:] Dziedzictwo i odpowiedź w sztuce wspótczesnej/Heritage and response in contemporary art, Łukasz Murzyn, Rafał Solewski, Sebastian Stankiewicz, Bernadeta Stano (eds.), Wydawnictwo Naukowe UP, Kraków 2018, pp. 233-246.

The Storyteller 1986, Tate, http://www.tate.org.uk/whats-on/tate-modern/exhibition/jeff-wall/room-guide/jeff-wall-room-4 (02. 07. 2013).

Stróżewski Władysław, Dialektyka twórczości, PWM, Kraków, 1983.

Stróżewski Władysław, Logos i mythos, in: idem, Logos, wartość, miłość, Kraków 2013, pp. 129-149.

Stróżewski Władysław, Wartości estetyczne i nadestetyczne [in:] idem, Wokót piękna. Szkice z estetyki, Universitas, Kraków 2002, pp. 180-205.

Szaman, http://pl.wikipedia.org/wiki/Szaman (01. 03. 2013).

Tisdall Caroline, Art into Society, Society into Art, ICA, London, 1974.

Warpechowski Zbigniew, Konserwatyzm awangardowy, Otwarta Pracownia, Kraków 2014.

Warpechowski Zbigniew, Konserwatyzm awangardowy 2, "Pressje”, 2015, no. 43, pp. 210-213.

Warpechowski Zbigniew, Obywatelstwo dla czystego odczucia Kazimierza Malewicza, https:// artmuseum.pl/pl/filmoteka/praca/warpechowski-zbigniew-obywatelstwo-dla-czystego-odczucia (20.05.2020).

Warpechowski Zbigniew, Statecznik, BWA, Lublin 2004.

Warpechowski Zbigniew, Zasobnik. Autorski opis trzydziestu lat drogi życia poprzez sztukę performance, stowo/obraz terytoria, Gdańsk 1998. 


\section{O SENSIE I O SOBIE. OPOWIEŚĆ W HERMENEUTYCZNEJ INTERPRETACJI SZTU- KI JOSEPHA BEUYSA, ZBIGNIEWA WARPECHOWSKIEGO I MIROSŁAWA BAŁKI. (streszczenie)}

Artykuł rozpoczyna przedstawienie hermeneutycznego założenia, że odpowiedź na wezwanie sensu do jego odkrywania w świecie i wypowiedź odnajdująca sens tożsamości osobowej w pogodzeniu stałości i zmienności mogą spotkać się w dziele sztuki i jego interpretacji, gdy rozumiane są one jako opowieść. Jako przykłady takich opowieści przedstawione zostają najpierw performatywne działania Josepha Beuysa łączącego prywatne dramatyczne doświadczenia z ujmowaniem siebie jako szamana, którego posłaniem jest uleczenie społeczeństw. Posłannictwem i ponoszeniem ofiary są opisane dalej działania i konsekwentna postawa w obrębie performatywnego i współczesnego naśladowania Chrystusa oraz „awangardowego konserwatyzmu” Zbigniewa Warpechowskiego. Wreszcie refleksyjne przyjmowanie dziedzictwa własnego i uniwersalnego wyrażane jest w instalacjach Mirosława Bałki, których poetycki charakter, czytelny w interpretacji, kryje w sobie sens. Właśnie interpretowanie artystycznych działań ujmowanych jako poetyckie opowieści pozwala, dzięki sztuce opisywanych artystów, odnajdywać sens na poziomie metafizyki, gdzie odsłaniają się uniwersalne wartości.

Słowa kluczowe: sens, tożsamość, hermeneutyka, opowieść, performans, instalacja, poetyka

Rafał Solewski - assistant professor at the Pedagogical University in Cracow, Department of Humanities, Chair of Art Studies. Author of the books: Umiar i namiętność. Życie i sztuka Janusza Orbitowskiego / Moderation and Passion. The Life and Art of Janusz Orbitowski, Kraków 2019; Wypatrujac. Idea człowieczeństwa i hermeneutyka tożsamości osobowej we wspótczesnych sztukach wizualnych [Watching Out. The Idea of Humanity and Hermeneutics of Personal Identity in Contemporary Visual Arts] (2016); Viatoris. Który pokonuje drogę. Ponowoczesny romantyzm Piotra Jargusza [Viatoris, one who travels the road. Postmodern romanticism of Piotr Jargusz] (2016); Skrytość piękna. Idealizm i problem tożsamości w sztukach wizualnych na przełomie XX $i$ XXI wieku [The Secretiveness of Beauty. Idealism and the Problem of Identity in Visual Arts at the Turn of the 21st Century] (2015); Synteza i wypowiedź. Poezja i filozofia w sztukach wizualnych na przełomie XX $i$ XXI wieku [Synthesis and Utterance. Poetry and Philosophy in Visual Art at the Turn of the 21st Century] (2007); Franciszek Maczyński (1874-1947) krakowski architekt [Franciszek Maczyński (1874-1974). A Cracovian Architect] (2005). He also published numerous articles in "Estetyka i Krytyka", "Kwartalnik Filozoficzny", "Art Inquiry", exhibition catalogues and conference materials. 